\title{
STRUKTUR ANATOMI DAUN SEBAGAI BUKTI DALAM PEMBATASAN TAKSON TUMBUHAN BERBUNGA: STUDI KASUS 12 SUKU TUMBUHAN BERBUNGA INDONESIA
}

\section{Leaf anatomical structure as evidence in flowering plants limitation: A case study of 12 Indonesian flowering plant families}

\author{
Tri Yuni Indah Wulansari*, Esthi Liani Agustiani, Sunaryo, Eka Fatmawati Tihurua, Widoyanti \\ Bidang Botani, Pusat Penelitian Biologi-LIPI, Jl. Raya Jakarta-Bogor, Km. 46, Cibinong, Bogor, 16911 \\ *Email: triyuniindahwulansari@yahoo.co.id
}

Diterima/Received: 30 Agustus 2019; Disetujui/Accepted: 27 Juli 2020

\begin{abstract}
Plant diversity not only can be seen by morphologically, but it can also be distinguished anatomically. Anatomical characters can be used to support and strengthen the plant classification. This study aimed to determine the anatomical character of the leaves which can be used as a taxonomic identifier at the level of taxa through species representation. A total of 15 species belonging to 12 Indonesian flowering plant families were examined using the paraffin method for the transversal section and $\mathrm{HNO}_{3}$ was used for the paradermal section. Some anatomical characters observed in this study can be used as family characteristics or even species characteristics. The result revealed that all examined samples had similar anatomical characters with previous studies which been carried out on the familial, genus and specific levels. These similar anatomical characters consist of one to several characteristic such as stomatal type, anticlinal cell wall, mesophyll tissue, and vascular bundle (petiole and midrib). These results indicated that some anatomical characters can be used as specific characteristics from familial to specific levels.
\end{abstract}

Keywords: midrib, petiole, stomatal type, vascular bundle

\begin{abstract}
Abstrak
Keanekaragaman tumbuhan tidak hanya terlihat secara morfologi, tetapi dapat dibedakan pula secara anatomi. Ciri anatomi dapat digunakan sebagai pendukung dan penguat pengklasifikasian jenis tumbuhan. Penelitian ini bertujuan untuk mengetahui ciri anatomi daun yang dapat digunakan sebagai penciri taksonomi dalam suatu tingkatan taksa melalui perwakilan jenis. Jenis yang digunakan berjumlah 15 , yang merupakan perwakilan dari 12 suku tumbuhan berbunga Indonesia. Metode parafin digunakan untuk mendapatkan penampang transversal dan metode perendaman dengan asam nitrat $\left(\mathrm{HNO}_{3}\right)$ digunakan untuk mendapatkan penampang epidermis daun. Sebagian ciri anatomi pada penelitian dapat digunakan sebagai penciri suku hingga jenis. Hasil penelitian menunjukkan bahwa 15 jenis yang diamati memiliki kesamaan ciri anatomi dengan data penelitian terdahulu yang telah dilakukan baik pada tingkat suku, marga maupun jenis. Kesamaan ciri anatomi tersebut mencakup satu hingga beberapa ciri seperti tipe stomata, dinding antiklinal sel epidermis, jaringan mesofil, dan berkas pengangkut (tangkai daun dan tulang tengah daun). Kesamaan ciri yang didapatkan pada masing-masing jenis menunjukkan bahwa ciri pada struktur anatomi daun dapat menjadi bukti pembatasan takson pada tumbuhan berbunga.
\end{abstract}

Kata kunci: berkas pengangkut, tangkai daun, tipe stomata, tulang tengah daun 


\section{PENDAHULUAN}

Struktur anatomi daun pada tumbuhan memiliki keanekaragaman yang tinggi. Daun tersusun atas berbagai macam jaringan, tiap jaringan dapat memberikan tampilan yang berbeda dan memberikan ciri khusus, sehingga ciri anatomi dapat digunakan sebagai alat pendukung dalam identifikasi, pengelompokan, dan hubungan kekerabatan jenis tumbuhan (Stuessy 1990). Hal yang sama dinyatakan oleh Dickinson (2000) dan Araujo et al. (2010), bahwa organ daun secara anatomi sangat bervariasi berdasarkan tingkat taksanya (jenis, marga, sampai suku) terlepas dari pengaruh lingkungan yang ekstrem. Penggunaan ciri anatomi sebagai sumber informasi dalam sistematika memerlukan pemahaman tentang variasi ciri dalam suatu marga atau suku yang dapat diwakili oleh satu individu, di antara spesimen dari jenis tertentu (Dickinson 2000).

Anatomi helaian daun beserta struktur khusus di dalamnya dapat digunakan sebagai ciri. Anna-santos et al. (2015) menggunakan ciri anatomi kristal oksalat dan serat silinder pada berkas pembuluh tulang tengah daun untuk membedakan Butia capitata (Mart.) Becc. dan B. odorata (Barb.Rodr.) Noblick yang secara morfologi sulit dibedakan. Marga Curtia dan Hockinia pada suku Gentianaceae dapat dibedakan berdasarkan tipe stomata, berkas pengangkut tulang tengah daun, tipe dan distribusi kelenjar nektar (Dalvi et al. 2014).

Bagian daun yang juga dapat digunakan sebagai ciri taksonomi adalah tangkai daun dan tulang tengah daun. Struktur jaringan penyusun tangkai daun dan tulang tengah daun digunakan sebagai pembeda dalam tingkat marga dan jenis pada beberapa takson dalam Rubiaceae (Kocsis \& Borhidi 2003), Dipterocarpaceae (Noraini et al. 2016) sampai ciri kunci taksonomi pada 23 jenis Anthurium seksi Urospadix subseksi Flavescentivirdia (Mantovani et al. 2009). Ciri tulang tengah daun dan tangkai daun yang telah digunakan sebagai ciri taksonomi di antaranya adalah bentuk dan jumlah berkas pengangkut (Ekeke et al. 2017), serta ciri lain seperti keberadaan sel sistolit dan lapisan hipodermis (Amri et al. 2018).

Kompleks Litsea (termasuk Neolitsea) dalam suku Lauraceae memiliki hubungan sistematika dalam tingkat marga dan dalam marga yang masih tidak jelas dan kontroversial (Li 2001), sehingga pengamatan ciri anatomi dapat membantu memecahkannya. Pada Styrax (Styracaceae), keberadaan trikoma bentuk bintang dapat digunakan sebagai penanda jenis (Fritsch 2005; Habermann et al. 2008). Koster \& Baas (1981) menyatakan bahwa dalam suku Myristicaceae, penggunaan ciri anatomi daun dapat digunakan untuk membedakan antar marga, bahkan memungkinkan pengelompokan jenis-jenis dalam satu marga, misalnya pada Horsfieldia. Marga Lophopetalum (Celastraceae) yang berkerabat dekat dengan marga Kokoona dapat dibedakan berdasarkan ciri anatominya (Jansen \& Baas 1973). Selain masih sangat terbatasnya informasi anatomi, jenis-jenis yang digunakan pada penelitian ini merupakan perwakilan dari beberapa suku yang mempunyai sebaran luas di Indonesia, dari Sumatra hingga Papua (Royal Botanic Garden 2017). Berdasarkan hal tersebut, penelitian ini bertujuan untuk mengetahui ciri anatomi daun yang dapat digunakan sebagai penciri taksonomi dalam suatu tingkatan taksa melalui perwakilan jenis.

\section{METODE}

\section{Spesimen tumbuhan}

Sampel daun dan tangkai daun didapatkan dari komunitas pohon hasil eksplorasi di hutan sekitar Danau Toba pada ketinggian $1700 \mathrm{~m}$ dpl dengan koordinat 02 $48667^{\prime \prime}-02^{\circ} 50223^{\prime \prime} L U$ dan 98²9134"-98²9685"BT pada Maret-April 2018. Setiap jenis diambil minimal tiga daun yang telah berkembang sempurna untuk dibuat preparat. Sebanyak 15 jenis dari 12 suku yang berbeda digunakan dalam penelitian ini (Tabel 1). Spesimen bukti disimpan di Herbarium Bogoriense (BO).

\section{Pembuatan dan pengamatan preparat anatomi}

Ciri anatomi daun dan tangkai daun dari 15 jenis tumbuhan diamati dengan membuat preparat sayatan transversal dan paradermal. Sampel daun dipotong dengan ukuran $1 \times 0,5 \mathrm{~cm}^{2}$ dan bagian tangkai daun dipotong dengan ukuran panjang 0,5$1 \mathrm{~cm}$ untuk pembuatan preparat sayatan transversal menggunakan metode parafin (Sass 1951). Daun difiksasi dengan larutan FAA, dilanjutkan perendaman sampel dalam larutan alkohol bertingkat dan xylol, pewarnaan 
menggunakan 1\% Safranin dan 2\% Fast Green. Pembuatan preparat paradermal dilakukan dengan memotong daun berukuran $1 \times 1 \mathrm{~cm}^{2}$. Pembuatan preparat paradermal berdasarkan pada Cutler (1978) dengan perebusan daun dalam larutan $\mathrm{HNO}_{3}$ untuk memisahkan bagian epidermis. Setiap jenis dibuat masing masing tiga slide preparat transversal dan paradermal.
Pengamatan dilakukan menggunakan mikroskop Nikon Eclipse 80i dan dilakukan minimal sebanyak 10 kali bidang pandang untuk setiap jenis, sesuai dengan ketersediaan seri sayatan yang utuh. Pemotretan dilakukan menggunakan kamera XCAM indomicro 1080 PHB perbesaran 2,4×2,4 pixel dengan aplikasi Beta View.

Tabel 1. Daftar jenis yang digunakan dalam penelitian

\begin{tabular}{|c|c|c|c|}
\hline No. & Nama Suku & Nama Jenis & Spesimen Voucher \\
\hline 1. & Cannabaceae & Gironniera hirta Ridl. & AS 577 \\
\hline 2. & Celastraceae & Lophopetalum javanicum (Zoll.) Turcz & AS 567 \\
\hline 3. & Clusiaceae & Garcinia dioica Blume & AS 747 \\
\hline 4. & Hypericaceae & Cratoxylum sumatranum (Jack) Blume & AS 425 \\
\hline 5. & Lauraceae & Cryptocarya densiflora Blume & AS 353 \\
\hline 6. & Lauraceae & Neolitsea triplinervia (Blume) Merr. & AS 694 \\
\hline 7. & Lauraceae & Cinnamomum sp.1 & AS 538 \\
\hline 8. & Lauraceae & Cinnamomum sp.2 & AS 563 \\
\hline 9. & Myristicaceae & Horsfieldia glabra (Blume) Warb. & AS 406 \\
\hline 10. & Phyllanthaceae & Bridelia glauca Blume & AS 361 \\
\hline 11. & Primulaceae & Ardisia complanata Wall. & AS 384 \\
\hline 12. & Rubiaceae & Wendlandia glabrata DC. & AS 743 \\
\hline 13. & Sapindaceae & Mischocarpus sundaicus Blume & AS 542 \\
\hline 14. & Sapotaceae & Palaquium rostratum (Miq.) Burck & AS 355 \\
\hline 15. & Styracaceae & Styrax benzoides W.G. Craib & AS 558 \\
\hline
\end{tabular}

\section{HASIL DAN PEMBAHASAN}

\section{Daun}

\section{a. Sayatan paradermal daun} Stomata

Lima tipe stomata, yaitu anomositik, parasitik, anisositik (Metcalfe \& Chalk 1950), tetrasitik, dan staurositik (van Cotthem 1970) (gambar 1a-1d) ditemukan pada 15 jenis tumbuhan yang diamati (Tabel 2). Penentuan tipe stomata didasarkan pada konfigurasi antara sel penjaga dan sel tetangga (Payne 1970). Seluruh jenis yang diamati memiliki kesamaan tipe stomata dengan data penelitian terdahulu yang telah dilakukan, baik pada tingkat suku, marga, maupun jenis.

Tipe stomata Gironniera hirta (Cannabaceae) adalah parasitik. Referensi anatomi pada marga Gironniera sangat terbatas. Anggota suku Cannabaceae lain yang memiliki tipe stomata parasitik adalah Cannabis sativa (Gangadhara et al.
1977), Celtis tessmannii, C. zenkeri (Sattarian 2006), dan C. australis (El-Alfy et al. 2011).

Lophopetalum javanicum (Celastraceae) memiliki tipe stomata parasitik. Tipe ini berbeda dengan yang dilaporkan oleh Jansen \& Baas (1973) yang menyatakan bahwa stomata $L$. javanicum adalah anisositik. Tholen \& Baas (1978) melaporkan bahwa dari segi suku, Celastraceae memiliki ciri tipe stomata yang beragam, salah satunya parasitik. Perbedaan hasil yang didapatkan tidak bisa dipastikan secara pasti penyebabnya karena minimnya sumber referensi mengenai stomata L. javanicum.

Tipe stomata parasitik juga dimiliki oleh Garcinia dioica (Clusiaceae), Styrax benzoides (Styracaceae), Cratoxylum sumatranum (Hypericaceae), Horsfieldia glabra (Myristicaceae), dan Bridelia glauca (Phyllanthaceae). G. dioica memiliki tipe stomata parasitik yang umum dimiliki oleh jenis lain pada marganya (Cardoso et al. 2013; 


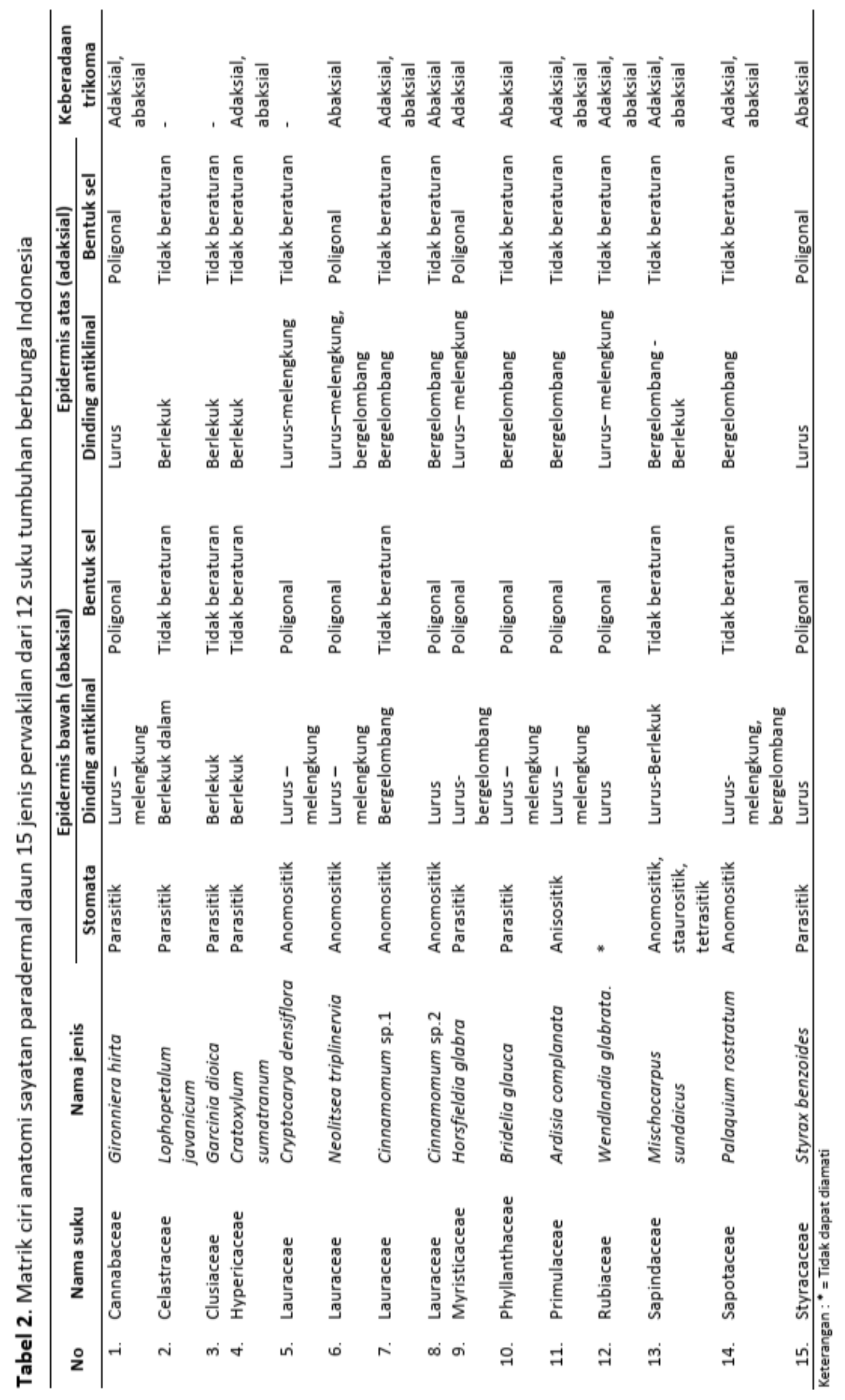


Lailati 2017; Priya \& Hari 2018). Stomata parasitik juga umum pada Styracaceae dan marga Styrax (Schadel \& Dickinson 1979) seperti contohnya $S$. benzoides. Jenis $C$. sumatranum mempunyai tipe stomata parasitik yang sama dimiliki oleh C. formosum subsp. formosum (Baas 1970). Bandumala (2007) menyatakan $H$. glabra memiliki tipe stomata parasitik yang juga dilaporkan pada $H$. iryaghedhi dan B. glauca memiliki stomata parasitik yang sama dengan $B$. moonii.

Tipe stomata anomositik dimiliki oleh empat jenis anggota Lauraceae, yaitu Cryptocarya densiflora, Neolitsea triplinervia, Cinnamomum sp.1, dan Cinnamomum sp.2. Stomata marga Cinnamomum dan Cryptocarya pada penelitian ini menguatkan hasil penelitian sebelumnya yang memperlihatkan bahwa kedua marga tersebut umumnya memiliki tipe stomata anomositik atau parasitik (Ravindran et al. 2005; Moraes 2006; Kumar 2013; Nishida et al. 2016). Tipe stomata anomositik pada $N$. triplinervia yang diamati memiliki tipe yang berbeda dari 52 jenis Neolitsea (Li 2001) yang memiliki tipe stomata parasitik. Keberadaan tipe stomata anomositik pada $N$. triplinervia merupakan catatan baru. Sebelumnya tipe anomositik dilaporkan hanya pada jenis $N$. cassia.

Palaquium rostratum (Sapotaceae) dan Mischocarpus sundaicus (Sapindaceae) juga memiliki tipe stomata anomositik. $M$. sundaicus memiliki tiga tipe stomata yaitu anomositik, tetrasitik, dan staurositik. Tipe stomata $M$. sundaicus yang dilaporkan pada penelitian ini sedikit berbeda dengan hasil pengamatan Norfaizal et al. (2018) yang menyebutkan bahwa $M$. sundaicus hanya memiliki dua tipe stomata, yaitu staurositik dan anomositik.

Tipe stomata pada Ardisia complanata (Primulaceae) adalah anisositik. Suku Primulaceae memiliki tiga tipe stomata yaitu anisositik, parasitik, dan anomositik. Pada sub suku Myrsinoideae diketahui bahwa tipe stomata yang dominan adalah anisositik. Tipe stomata ini ditemukan pada marga Ardisia, Myrsine, dan Stylogyne. Tipe stomata anomositik ditemukan pada Jacquinia armillaris Jacq. sebagai perwakilan dari sub suku Theophrasoideae, sedangkan tipe parasitik ditemukan pada marga Cybianthus (Luna et al. 2013; Luna et al. 2017; Kuster et al. 2018).
Ketersediaan data anatomi yang terbatas membuat beberapa jenis hanya dapat dibandingkan dengan jenis lain yang berbeda atau lintas marga, sehingga pembatasan taksonomi hanya dapat dilakukan pada tingkat yang terbatas. Pada tingkat suku, jenis yang menunjukkan tipe stomata mewakili ciri sukunya adalah G. hirta, L. javanicum, $C$. densiflora, dan $P$. rostratum. Untuk jenis yang menunjukkan kesamaan tipe stomata dengan jenis lain pada tingkat marga adalah $G$. dioica, $C$. sumatranum, Cinnamomum spp., H. glabra, B. glauca, A. complanata, dan S. benzoides. Sedangkan jenis yang menunjukkan ciri spesifik jenis adalah $M$. sundaicus dengan tiga tipe stomata (anomositik, tetrasitik dan staurositik) serta $N$. triplinervia dengan tipe stomata anomositik, dimana pada umumnya tipe stomata marga ini adalah parasitik. Hal ini membuktikan bahwa tipe stomata dapat digunakan sebagai ciri untuk pembatasan takson tumbuhan berbunga (Gole et al. 2013; Khan et al. 2014).

\section{Dinding sel epidermis}

Berdasarkan Tabel 2 dapat diketahui bahwa jenis yang memiliki tipe stomata sama belum tentu memiliki bentuk sel epidermis dan tipe dinding antiklinal yang sama (Yang et al. 2012; Luna et al. 2013; Goncalves et al. 2018). Dinding antiklinal pada pengamatan ini diklasifikasikan menjadi empat tipe, yaitu lurus, melengkung, bergelombang, dan berlekuk dengan sel epidermis berbentuk poligonal dan tidak beraturan (Gambar 1e-1g). Dinding sel antiklinal dikatakan lurus, jika dinding tersebut membentuk sudut, sedangkan dinding melengkung terindikasi dengan dinding antiklinal bergaris lurus tetapi tanpa pembentukan sudut. Dinding sel antiklinal dikatakan bergelombang jika dinding tersebut membentuk satu gunung dan satu lembah dan dinding berlekuk yaitu dinding antiklinal yang mempunyai lebih dari satu gunung dan lembah (Yang et al. 2012; Norfaizal et al. 2018).

Hasil pengamatan terhadap dinding antiklinal sel epidermis pada seluruh jenis menunjukkan hasil yang mirip dengan ciri masingmasing suku, marga atau jenis. Pada tingkat suku, Gironniera hirta (Cannabaceae) memiliki kesamaan dengan Cannabis sativa (Gangadhara et al. 1977) dan Celtis pallida (Maiti et al. 2016). Palaquium rostratum (Sapotaceae) memiliki epidermis atas bergelombang yang sesuai dengan Manilkara 
zapota (Nagani et al. 2012) dan epidermis bawah lurus hingga melengkung yang sesuai dengan Manilkara hexandra (Chanda et al. 2010). Pada Styrax benzoides (Styracaceae) dinding antiklinalnya sesuai dengan Schadel \& Dickinson (1979) yang menyatakan Styracaceae memiliki dinding antiklinal atas dan bawah lurus sampai melekuk.

Dinding antiklinal dan bentuk sel epidermis pada anggota Lauraceae pada penelitian ini menggambarkan kesamaan tingkat suku dan keberagaman tingkat marga. Jenis dari Lauraceae memiliki bentuk dinding antiklinal dan sel epidermis yang berbeda. Yang et al. (2012) juga mendapatkan dinding antiklinal yang sangat beragam pada suku Lauraceae marga Beischiedia, Endiandra, Potameia, Sinopora, dan Syndiclis.

Beberapa sampel memiliki kesamaan dengan jenis lain dalam tingkat marga. Dinding antiklinal epidermis bawah Horsfieldia glabra (Myristicaceae) sesuai dengan jenis $H$. iryaghedhi (Bandumala 2007), sedangkan dinding antiklinal atas Horsfieldia mendukung pernyataan Koster \& Baas (1981) yaitu lurus-melengkung hingga berlekuk. Bridelia glauca (Phyllanthaceae) memiliki epidermis bawah sama dengan $B$. moonii (Bandumala 2007) dan Ardisia complanata (Primulaceae) memiliki bentuk dinding antiklinal bawah sesuai dengan $A$. guianensis dan A. humilis, sedangkan dinding antiklinal atas menyerupai $A$. solanaceae (Luna et al. 2017).

Dinding antiklinal $G$. dioica berlekuk, baik pada epidermis atas dan bawahnya. Penelitian Wang et al. (2017) dan Nidyasari et al. (2018) menunjukkan bahwa sebagian besar dinding antiklinal pada Garcinia adalah lurus. Satu jenis yang memiliki dinding antiklinal sama dengan $G$. dioica yaitu $G$. Malaccensis (Nidyasari et al. 2018). Hal ini memungkinkan dinding antiklinal $G$. dioica sebagai penciri jenis.

Terdapat tiga sampel yang dapat dibandingkan pada tingkat jenis. Dinding antiklinal Mishocarpus sundaicus sesuai dengan penelitian Norfaizal et al. (2018), sedangkan dua jenis lain menunjukkan hasil yang berbeda dengan penelitian terdahulu yaitu Cratoxylum sumatranum (Hypericaceae) dan Lophopetalum javanicum (Celastraceae). C. sumatranum dinding antiklinal sel melekuk namun hasil Baas (1970) pada jenis yang sama menyatakan lurus hingga melengkung. Hasil pengamatan dinding antiklinal atas dan bawah $L$. javanicum melekuk, sedangkan penelitian Jansen \& Baas (1973) menyatakan lurus hingga melengkung. Perbedaan ini tidak dapat diketahui secara pasti penyebabnya, namun beberapa penelitian menunjukkan bahwa faktor lingkungan dapat berpengaruh terhadap perbedaan dinding antiklinal suatu jenis. Sharma \& Davis (2001) menyatakan perubahan puncak gelombang dinding antiklinal epidermis dan kerapatan stomata pada Parthenocissus quinquefolia terjadi karena paparan polusi. Nughes et al. (2013) melaporkan bahwa pada jenis yang memiliki plastisitas fenotip seperti Celtis ehrenbergiana, pengaruh naungan menjadikan dinding antiklinal yang awalnya lurus berubah menjadi bergelombang hingga berlekuk.

\section{b. Sayatan transversal daun}

Pengamatan secara transversal menunjukkan bahwa semua jenis yang diamati memiliki epidermis atas dan epidermis bawah daun yang terdiri atas satu lapis sel (uniseriate). Beberapa penelitian juga menunjukkan bahwa jumlah lapisan epidermis dapat digunakan sebagai ciri taksonomi pada tingkat marga (Devecchi et al. 2014; Lin \& Tan 2015; Akinsulire et al. 2018), sedangkan epidermis ganda (multiple epidermis) ditemukan pada Rhizoporaceae (Stace 1965) dan Pandanaceae (Rahayu et al. 2011).

Tipe daun pada seluruh jenis adalah dorsiventral, kecuali pada G. hirta yang memiliki tipe daun isobilateral homogen. Tipe isobilateral umum ditemukan pada monokotil. Namun pada beberapa kasus, tipe isobilateral ditemukan pada daun dikotil dan dapat digunakan sebagai ciri takson tingkat jenis (Seshavataram \& Srivalli 1989; Perrone et al. 2013). Data anatomi pada marga Gironniera masih sangat terbatas.

Ciri anatomi lain yang ditemukan pada sampel di antaranya adalah parenkim tiang dua lapis yang dimiliki oleh $M$. sundaicus, W. glabrata, $L$. javanicum, dan $C$. sumatranum. Parenkim tiang dua lapis $M$. sundaicus dan $C$. sumatranum memperkuat ciri takson pada tingkat marga (Baas 1970; Turner 1994), sedangkan W. glabrata pada tingkat suku (Tilney et al. 1990). Pada beberapa jenis dari Rubiaceae menunjukkan adanya parenkim tiang dua lapis yaitu pada Canthium, Psydax (Tilney et al. 1990), dan Cordiera (Teixeira et al. 2016). Hasil yang berbeda terlihat pada $L$. javanicum dengan Jansen 
\& Baas (1973) yang menunjukkan satu lapis jaringan tiang. Metcalfe \& Chalk (1950) dan Bandumala (2007) menyatakan bahwa lingkungan dapat mempengaruhi keberadaan (distribusi) dan jumlah lapisan jaringan mesofil.

Hipodermis ditemukan pada W. glabrata, H. glabra, dan C. densiflora. Hipodermis pada $H$. glabra menunjukkan ciri marga dan memperkuat Koster \& Baas (1981) yang menyatakan hipodermis pada Horsfieldia umumnya tersusun oleh sel yang tidak sama besar dan terdapat sel-sel yang membengkak dengan dinding sel yang lebih tipis, sedangkan pada $C$. densiflora menunjukkan ciri jenis yaitu hipodermis atas $C$. densiflora hanya terdapat pada bagian tulang tengah daun, sedangkan hipodermis pada beberapa jenis Cryptocarya dijumpai pada bagian atas maupun bawah daun seperti pada Cryptocarya aff. aschersoniana Mez (Moraes 2006).
Beberapa jenis yang diamati menunjukkan adanya kristal kalsium oksalat, yaitu $G$. dioica, $H$. glabra, dan A. complanata (Hambar 1i-k). Pada bagian mesofil Garcinia dioica ditemukan kristal kalsium oksalat bentuk druse, hal ini sesuai dengan G. morella dan G. spicata (Pathirana \& Herat 2004), G. brasiliensis (Cardoso et al. 2013), G. indica (Priya \& Hari 2018), dan dapat digunakan sebagai penciri jenis. Bentuk kristal kalsium oksalat pada H. glabra dan $A$. complanata dari hasil pengamatan juga berbentuk druse.

Trikoma ditemukan pada hampir seluruh sampel yang diamati dan sebagian besar terletak pada bagian permukaan bawah. Pada epidermis bawah $S$. benzoides terlihat jelas adanya trikoma bentuk bintang (Gambar 1h). Anggota Styracaceae hampir seluruhnya memiliki trikoma dengan bentuk stellate, peltate, atau cylindrical (Schadel \& Dickinson 1979) dan dapat digunakan sebagai ciri taksonomi.

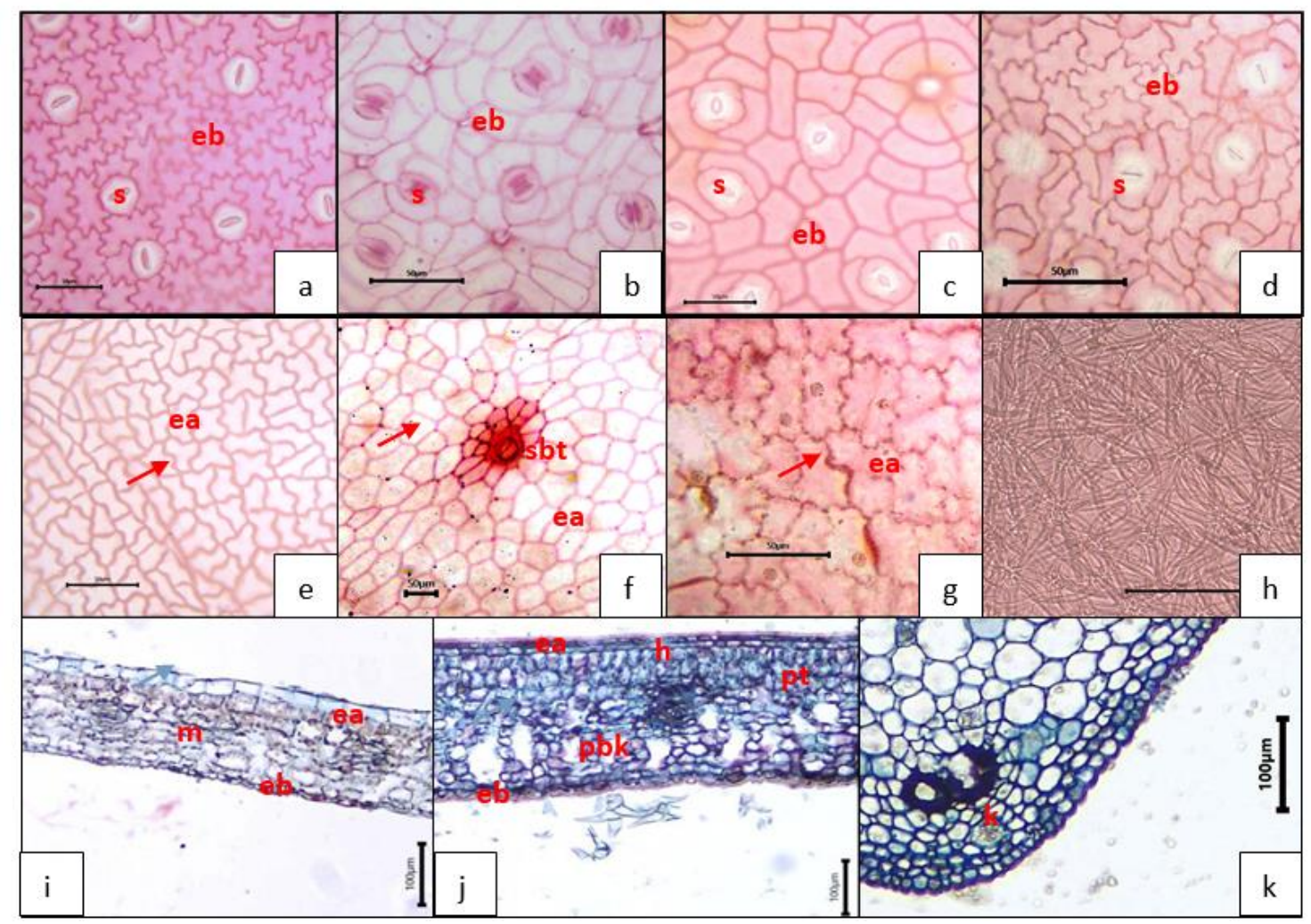

Keterangan: ea = epidermis atas, eb = epidermis bawah, $\mathrm{s}=$ stomata, sbt $=$ sel basal trikoma, $\mathrm{h}=$ hipodermis, $\mathrm{m}=\mathrm{mesofil}$, pt $=$ parenkim tiang, pbk = parenkim bunga karang, $\mathrm{k}=$ kristal kalsium oksalat, dan tanda panah $=$ dinding antiklinal.

Gambar 1. Contoh tipe stomata dan dinding antiklinal yang ditemukan pada 15 jenis perwakilan dari 12 suku tumbuhan berbunga Indonesia (a-g). (a) parasitik pada Cratoxylum sumatranum; (b) anomositik pada Cryptocarya densiflora; (c) anisositik pada Ardisia complanata; (d) staurositik pada Mischocarpus sundaicus; (e) dinding antiklinal sel epidermis atas bergelombang pada Cinnamomum sp.2; (f) dinding antiklinal sel epidermis atas lurus pada Gironniera hirta; (g) dinding antiklinal sel epidermis atas berlekuk pada Garcinia dioica, (h) trikoma bentuk bintang pada Styrax benzoides. Contoh penampang transversal daun (i-k). (i). mesofil isolateral homogen pada Gironniera hirta, (j) Wendlandia glabrata dengan hipodermis atas dan parenkim tiang dua lapis dan (k) kristal kalsium oksalat Ardisia complanata. 


\section{Berkas pengangkut tangkai daun dan tulang tengah daun}

Ciri anatomi yang diamati antara lain pola berkas pengangkut, keberadaan sklerenkim, kristal oksalat, dan sel sekretori (Tabel 3). Tipe berkas pengangkut diklasifikasikan berdasarkan bentuknya (Metcalfe \& Chalk 1950).

\section{Tangkai Daun}

Enam tipe berkas pengangkut pada tangkai daun (Gambar 2) ditemukan pada 15 jenis yang diamati. Tipe yang paling umum ditemukan adalah busur dan busur menekuk yang mencakup 11 jenis, sedangkan empat tipe lain ditemukan pada M. sundaicus (busur setengah menekuk), H. glabra (bulan sabit), A. complanata (huruf $\mathrm{V}$ terputus dengan tambahan dua berkas pengangkut), dan G. hirta (spiral).

Bentuk tangkai daun anggota Lauraceae menunjukkan ciri suku, karena adanya kesamaan pada bentuk tangkai daun yaitu busur dan busur menekuk (Moraes 2006; Kumar 2013; Serebrynaya et al. 2017; Abeysinghe \& Scharaschkin 2019). Metcalfe (1987) menyatakan beberapa marga dari Lauraceae juga dicirikan oleh adanya sel sekretori di beberapa organ. Pada penelitian ini, sel sekretori ditemukan pada tulang tengah daun $C$. densiflora dan Cinnamomum sp.2, serta tangkai daun $N$. triplinervia.

Tipe tangkai daun yang mencirikan tingkatan marga ditemukan pada $G$. dioica, C. sumatranum, B. glauca, A. complanata, dan S. benzoides. Marga Garcinia memiliki bentuk berkas pengangkut tangkai daun yang umumnya berbentuk busur menekuk (Pathirana \& Herat 2004; Abreu et al. 2017; Priya \& Hari 2018). Bentuk berkas pengangkut C. sumatranum adalah busur dengan ujung menekuk. Pada tangkai daun $C$. sumatranum ditemukan adanya kristal yang berbentuk druse, selain itu juga dicirikan dengan adanya sel sekretori (Baas 1970). B. glauca memiliki bentuk busur sesuai dengan penelitian Thakur \& Patil (2011) yang dilakukan pada B. stipularis. Berkas tangkai daun $A$. complanata sesuai dengan penelitian Luna et al. (2017) terhadap 33 anggota Primulaceae yaitu busur menekuk, sedangkan pada S. benzoides sesuai dengan Schadel \& Dickinson (1979) yang menyatakan Styrax umumnya memiliki tangkai daun bentuk busur, busur dengan ujung menekuk, atau silinder dengan tambahan berkas pengangkut.
Jenis-jenis dalam penelitian yang memiliki tipe berkas pengangkut berbeda jika dibandingkan dengan data jenis lain dalam satu marga ataupun satu suku adalah G. hirta, $H$. glabra, dan $P$. rostratum. Berkas pengangkut tangkai daun $G$. hirta memiliki tipe spiral dan $P$. rostratum memiliki tipe huruf $\mathrm{V}$ terputus, belum terdapat data berkas tangkai daun pada kedua marga tersebut. H. glabra memiliki bentuk berkas tangkai daun bulan sabit, sedangkan diagram yang dibuat Koster \& Baas (1981) cenderung cembung pada bagian atas. Hal ini memungkinkan tipe tangkai daun yang spesifik pada ketiganya dapat menjadi ciri jenis.

\section{Tulang Tengah Daun}

Berkas pengangkut pada tulang tengah daun memiliki tipe yang bervariasi. Berdasarkan bentuknya, terdapat tujuh tipe berkas pengangkut, yaitu tipe jantung ( 5 jenis), busur landai (4 jenis), bentuk bibir (2 jenis), dan lainnya masing-masing dimiliki oleh satu jenis (Gambar 3).

Terbatasnya data anatomi tulang tengah daun menyebabkan pembandingan hasil pengamatan sebagian besar dilakukan dengan jenis lain (antar marga) pada suku yang sama. Hasil pengamatan menunjukkan hampir seluruh jenis memiliki kemiripan dengan beberapa anggota sukunya. Persamaan dalam tingkat marga dimiliki oleh G. dioica (Pathirana \& Herat 2004), sedangkan jenis yang tidak ditemukan berkas pengangkut yang sama dalam sukunya adalah $G$. hirta dan $H$. glabra. Perbedaan berkas pengangkut yang mencolok ini memungkinkan menjadi ciri spesifik jenis.

Kristal kalsium oksalat dan sel sekretori ditemukan pada daerah parenkim tulang tengah daun beberapa jenis. Kristal kalsium oksalat ditemukan pada $A$. complanata, $C$. sumatranum, H. glabra, dan G. dioica, yang digunakan sebagai ciri jenis (Baas 1970; Pathirana \& Herat 2004; Luna et al. 2017). Bentuk dan kehadiran kristal kalsium oksalat pada organ tumbuhan dapat menjadi ciri spesifik taksonomi, seperti pada dua marga berbeda dalam suku Piperaceae (Horner et al. 2012) dan pada beberapa jenis suku Asteraceae (KartalMeric 2016). Keberadaan kristal oksalat dapat terdeposit pada jaringan dan organ tumbuhan, seperti pada jaringan mesofil daun dan jaringan empulur batang (Franceschi \& Nakata 2005; Konyar et al. 2014). Ciri anatomi lain yang hanya terdapat pada beberapa jenis adalah sel dan 


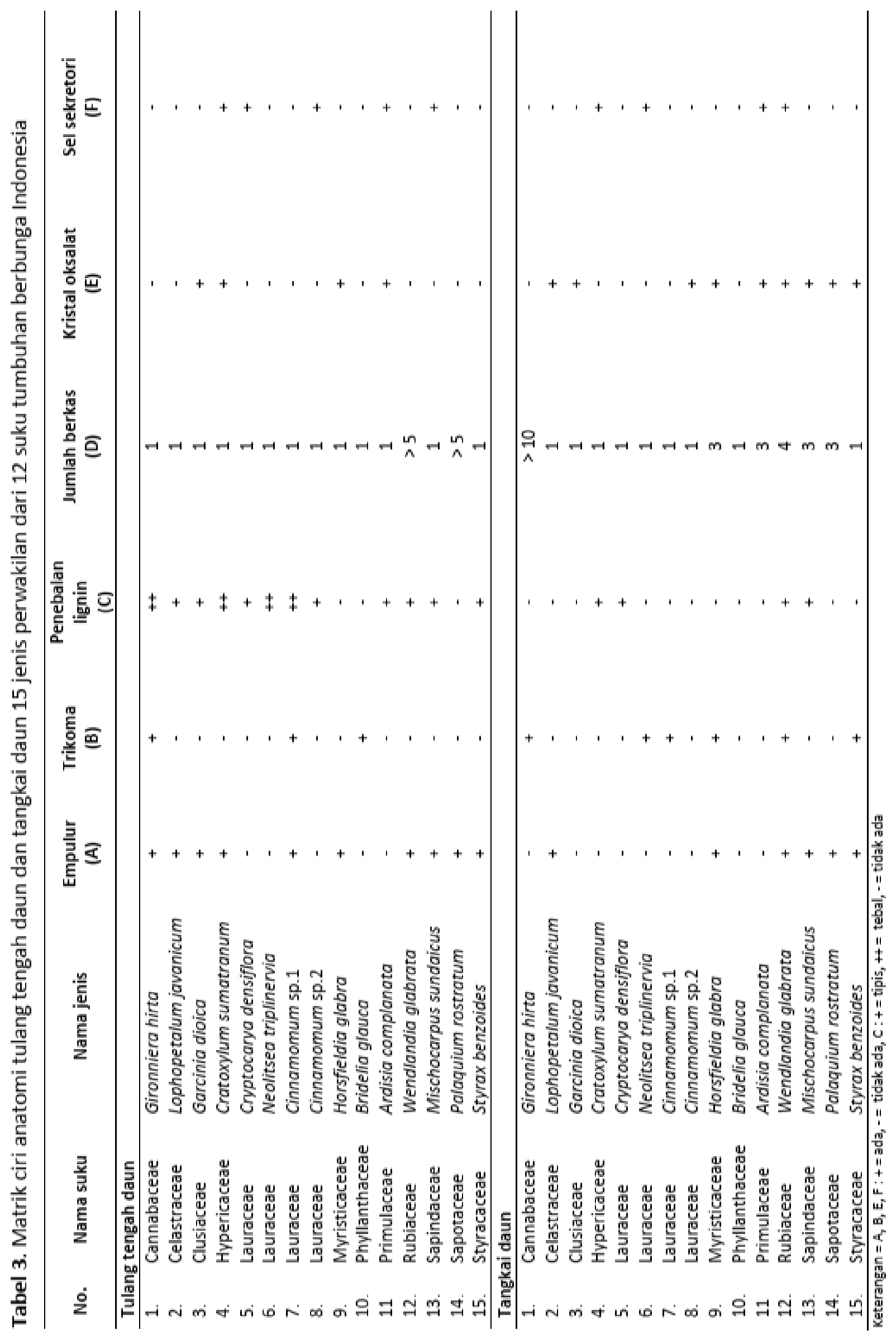


kelenjar sekretori, yaitu $C$. densiflora dan Cinnamomum sp.2 dengan tipe sel sekretori dan A. complanata, C. sumatranum, M. sundaicus dengan tipe kelenjar sekretori.

Berkas pengangkut tulang tengah daun dan tangkai daun merupakan suatu struktur yang saling berhubungan. Bentuk berkas pengangkut tulang tengah daun merupakan perkembangan dari tangkai daun (Jansen \& Baas 1973; Schadel \& Dickinson 1979). Beberapa jenis menunjukkan bentuk berkas pengangkut yang sama atau hampir sama dan sebagian menunjukkan bentuk yang sangat berbeda (Tabel 4). Schadel \& Dickinson (1979) menggambarkan diagramatik tangkai daun bentuk busur yang berkembang menjadi tulang tengah daun bentuk busur, busur menekuk, jantung, dan bentuk jantung yang kompleks. Pathirana \& Herat (2004) menggambarkan diagramatik perkembangan tangkai daun bentuk busur menekuk menjadi berbagai tipe berkas pengangkut jantung dan modifikasinya.

Tabel 4. Perbandingan sketsa anatomi berkas pengangkut tangkai daun dan tulang tengah daun pada 15 jenis perwakilan 12 suku tumbuhan berbunga Indonesia

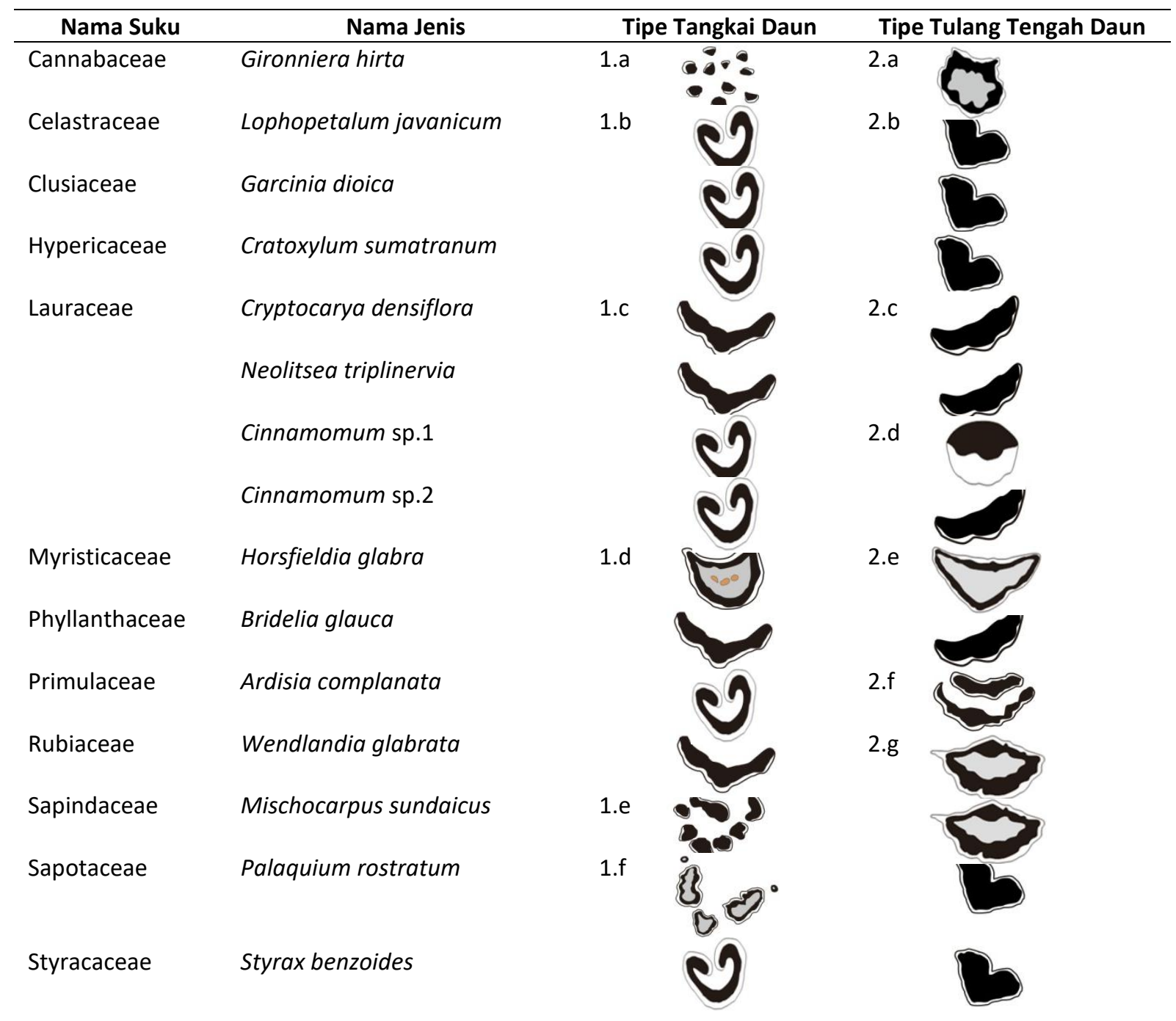

Keterangan: skema berkas pengangkut tangkai daun (1a-1f): 1a. spiral, 1b. busur menekuk, 1c. busur, 1d. bulan sabit, 1e. busur setengah menekuk, dan $1 \mathrm{f}$. huruf $\mathrm{V}$ terputus dengan tambahan 2 berkas pengangkut. Skema berkas pengangkut tulang tengah daun ( $2 a-$ 2g): 2a. tiga seperempat lingkaran, 2b. jantung, 2c. busur landai, 2d. oval, 2e. bulan sabit, 2f. busur dengan tambahan berkas pengangkut, dan $2 \mathrm{~g}$. menyerupai bibir. Warna hitam: xylem, putih: floem, dan kelabu: empulur. 
Perubahan dan perkembangan berkas pengangkut dapat dilihat secara jelas jika dilakukan potongan pada basal, median, dan distal tangkai daun serta tulang tengah daun. Koster \& Bass (1981) menyatakan bahwa bentuk berkas pengangkut tulang tengah daun seringkali sama dengan berkas pengangkut tangkai daun bagian distal. Namun, pada beberapa marga atau jenis, seperti L. javanicum memiliki penampakan bagian basal, median, distal, dan tulang tengah daun yang sangat berbeda dan kompleks (Jansen \& Baas 1973).
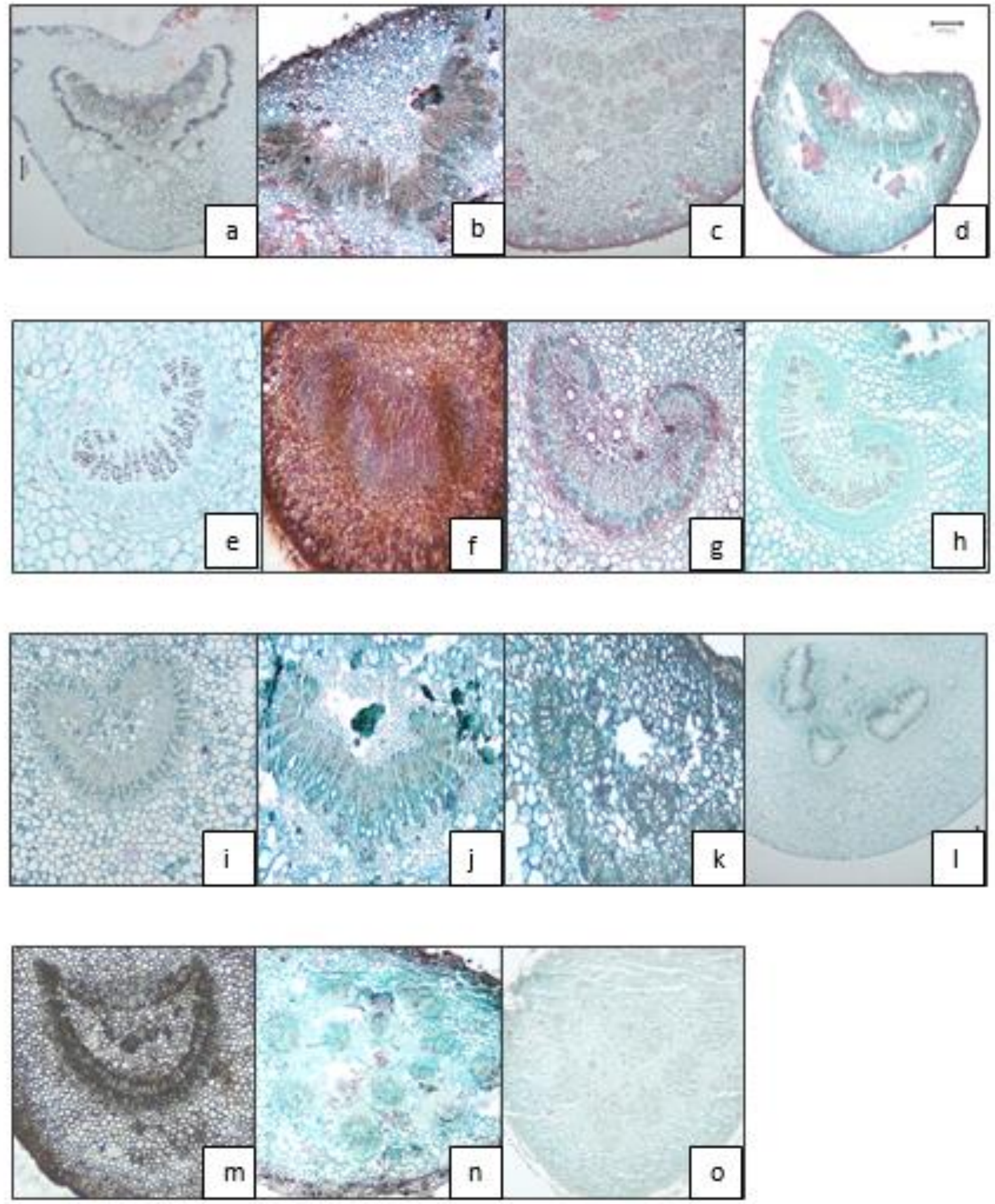

Gambar 2. Berkas pengangkut tangkai daun bentuk busur (a-d), (a) C. densiflora, (b) B. glauca, (c) W. glabrata, (d) N. triplinervia; bentuk busur menekuk (e-k), (e) G. dioica, (f) Cinnamomum sp.1, (g) C. sumatranum, (h) S. benzoides, (i) L. javanicum, (j) Cinnamommum sp.2, (k) A. complanata, (I) bentuk V terputus dengan 2 tambahan berkas pengangkut pada $P$. rostratum, $(\mathrm{m})$ bentuk bulan sabit pada $H$. glabra, (n) bentuk spiral pada $G$. hirta, dan (o) bentuk busur setengah menekuk pada $M$. sundaicus. 

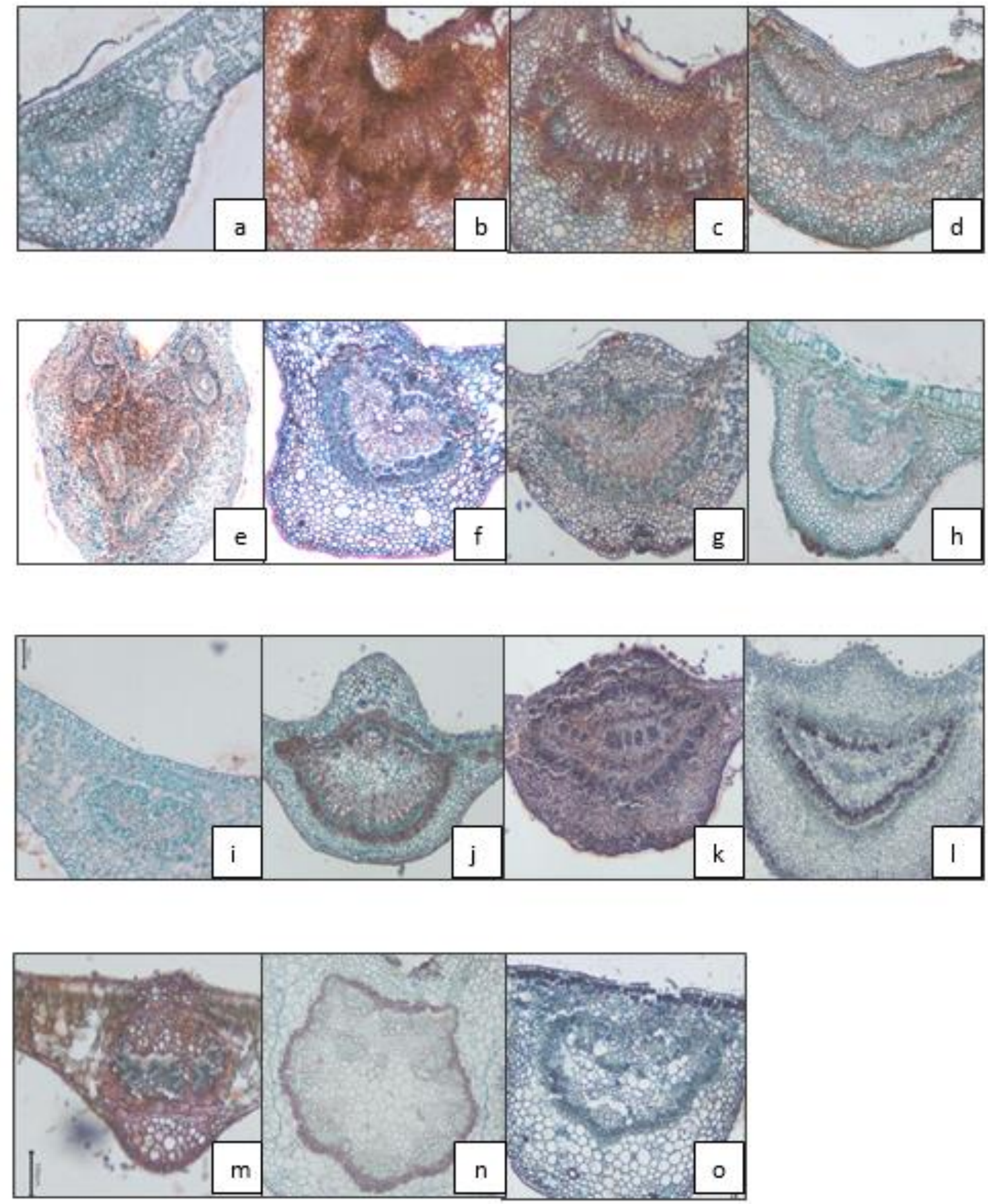

Gambar 3. Berkas pengangkut tulang tengah daun bentuk busur landai (a-d), (a) C. densiflora, (b) B. glauca, (c) Cinnamomum sp.2, (d) N. triplinervia; bentuk jantung (e-i), (e) P. rostratum, (f) C. sumatranum, (g) S. benzoides, (h) L. javanicum, (i) G. dioica; menyerupai bibir (j-k), (j) M. sundaicus, (k) W. glabrata, (I) bentuk bulan sabit pada H. glabra, (m) bentuk oval pada Cinnamomum sp.2, (n) bentuk tiga perempat lingkaran pada $G$. hirta, dan (o) bentuk busur dengan tambahan berkas pengangkut pada $A$. complanata. Keterangan: $\mathrm{x}=\mathrm{xilem}$ dan $\mathrm{f}=$ floem. 


\section{KESIMPULAN}

Ciri anatomi daun dapat digunakan sebagai penciri taksonomi dalam suatu tingkatan taksa melalui perwakilan jenis. Beberapa ciri anatomi daun dapat menjadi ciri spesifik pada tingkat jenis, namun tak jarang terdapat ciri yang hanya mampu menunjukkan ciri spesifik pada tingkat marga dan suku. Keterbatasan data penelitian terdahulu dan jumlah jenis yang digunakan, menyebabkan pembatasan yang tegas belum bisa dilakukan. Penelitian anatomi yang lebih menyeluruh yang melibatkan perwakilan jenis dari semua marga dari tiap suku tumbuhan berbunga di Indonesia merupakan sebuah tantangan yang besar untuk dilakukan di masa mendatang.

\section{UCAPAN TERIMA KASIH}

Penelitian ini didanai oleh proyek penelitian DIPA dari Pusat Penelitian Biologi-Lembaga IImu Pengetahuan Indonesia tahun 2018. Penulis pertama dan kedua mengucapkan banyak terima kasih kepada dua orang pembimbing, Prof. Dr. Andria Agusta (Pusat Penelitian Biologi-LIPI) dan Dr. Titien Ng. Praptosuwiryo (Pusat Penelitian Konservasi Tumbuhan dan Kebun Raya-LIPI), yang telah memberikan masukan, ulasan kritis, dan saran demi perbaikan naskah ini. Ucapan terima kasih juga disampaikan kepada Bapak Asep Sadili dan Ujang Hapid yang telah memberikan bantuan dalam pengambilan dan pemberian informasi terkait sampel penelitian, serta Dita Pratama yang telah memberikan bantuan dalam penyelesaian naskah.

\section{DAFTAR PUSTAKA}

Abeysinghe PD, Scharaschkin T. 2019. Taxonomic value of the petiole anatomy in the genus Cinnamomum (Lauraceae) found in Sri Lanka. Ruhuna Journal of Science 10(1): 117. DOI: http://doi.org/10.4038/rjs.v10i1. 47.

Abreu NDC, Barbosa SM, Gurgel ESC, De Carvalho WV. 2017. Morphoanatomy of Garcinia madruno (Kunth) Hammel (Clusiaceae) under waterlogged conditions. Revista Brasileira de Fruticultura 39(5): 1-8. DOI: 10.1590/0100-29452017012.
Akinsulire OP, Oladipo OT, Akinloye AJ, Illoh HC. 2018. Structure, distribution and taxonomic significance of leaf and petiole anatomical characters in five species of Terminalia (L.) (Combretaceae: Magnoliopsida). Brazilian Journal of Biological Sciences 5(10): 515528.

Amri CNAC, Tajudin NS, Shahari R, Azmi FM, Talip N, Mohamad AL. 2018. Comparative leaf anatomy of selected medicinal plants in Acanthaceae. International Medical Journal Malaysia 17(2): 17-23.

Anna-santos BFS, Junior WGOC, Amaral VB. 2015. Butia capitata (Mart.) Becc. lamina anatomy as a tool for taxonomic distinction from $B$. odorata (Barb. Rodr.) Noblick comb. Nov (Arecaceae). Annals of the Brazilian Academy of Sciences 87(1): 71-81.

Araujo JS, Azevedo AA, Silva LC, Meira RMSA. 2010. Leaf anatomy as an additional taxonomy tool for 16 species of Malpighiaceae found in the Cerrado Area (Brazil). Plant Systematics and Evolution 286: 117-131.

Baas P. 1970. Anatomical contributions to plant taxonomy I : Floral and vegetative anatomy of Eliea from Madagascar and Cratoxylum from Indo-Malesia (Guttiferae). Blumea 18(2): 369-391.

Bandumala S. 2007. Seedling leaf structure of three species in relation to their successional status and canopy position in a Sri Lankan Rain Forest. Thesis. University of Sri Jayewardenepura. (diakses 13 Juni 2019)

Cardoso AA, Pereira FJ, Pereira MP, Correa FF, de Castro EM, Santos BR. 2013. Anatomy of stem, leaves, roots and the embryo of Garcinia brasiliensis Mart.-Clusiaceae. Amazonian Journal of Agricultural and Enviromental Sciences 56: 23-29.

Chanda S, Nagani K, Parekh J. 2010. Assessment of quality of Manilkara hexandra (Roxb.) Dubard leaf (Sapotaceae): pharmacognostical and physiochemical profile. Pharmacognosy Journal 2(3): 520-524.

Cutler DF. 1978. Applied plant anatomy. Longman. London and New York.

Dalvi VC, Meira RMSA, Francino DMT, Silva LC, Azevedo AA. 2014. Anatomical characteristics as taxonomic tools for the species of Curtia and Hockinia (Saccifolieae- 
Gentianaceae Juss.). Plant Systematics and Evolution 300: 99-112.

Devecchi MF, Pirani JR, Melo-de-Pina GFA. 2014. Comparative leaf anatomy and morphology of some brazilian species of Crotalaria L. (Leguminosae: Papilionoideae: Crotalarieae). Acta Botanica Brasilica 28(4): 583-593. DOI: 10.1590/010233062014abb 3517

Dickinson WC. 2000. Integrative Plant Anatomy. Harcourt Academic Press. San Diego.

Ekeke CIO, Agbagwa, Ogazie AC. 2017. Comparative anatomy of stem, petiole and flower stalks and its significance in the taxonomy of some members of Cucurbits. Jordan Journal of Biological Sciences 10(3): 185-191.

El-Alfy TSMA, El-Gohary HM, Sokkar NM, El-Tawab SA, Al-Mahdy DAM. 2011. Botanical and genetic characteristics of Celtis australis L. and Celtis occidentalis L. grown in Egypt. Bulletin of Faculty of Pharmacy 49: 37-57.

Franceschi VR, Nakata PA. 2005. Calcium oxalate in plants: formation and function. Annual Review of Plant Biology 56: 41-71.

Fritsch PE. 2005. A New Species of Styrax (Styracaceae) from Southern Mexico. Department of Botany, California Academy of Sciences.

Gangadhara M, Inamdar JA, Vidyanagar V. 1977. Trichomes and stomata, and their taxonomic significance in The Urticales. Plant Systematics and Evolution 127: 121-137.

Gole AA, Ramugade MA, Bhagwat HR, Gaikwad SS, Mohite PC, Aparadh VT. 2013. Taxonomic diversity of stomata in some Angiospermic plants Satara Region India. IRJPAS 3(1): 5255.

Goncalves RA, Pinheiro AB, Oliveira $M A$, Nascimento RT, Rosalem PF, Garcia VL, Martins AR. 2018. Anatomical characters and chemical profile of leaves of three species in Lauraceae family. Brazilian Journal of Pharmacognosy 28: 1-8.

Habermann G, Machado SR, Guimaraes VF, Rodrigues JD. 2008. Leaf heliotropism in Styrax camporum Pohl from the Brazilian Cerrado-Distict gas exchange and leaf structure, but similar leaf temperature and water relations. Brazilian Journal of Plant Physiology 20(1): 71-83.
Horner HT, Wanke S, Samain M-S. 2012. A comparison of leaf crystal macropatterns in the two sister genera Piper and Peperomia (Piperaceae). American Journal of Botany 99: 983-997.

Jansen WT, Baas P. 1973. Comparative leaf anatomy of Kokoona and Lophopetalum (Celastraceae). Blumea 21: 153-178.

Kartal-Meric C. 2016. Calcium oxalate crystals in some species of the tribe cardueae (Asteraceae). Botanical Sciences 94(1): 107119. DOI:10.17129/botsci.259

Khan F, Yousaf Z, Ahmed HS, Arif A, Rehman HA, Younas A, Rashid M, Tariq Z, Raiz N. 2014. Stomatal patterning: An important taxonomic tool for systematical studies of tree species of angiosperm. Annual Research and Review in Biology 4(24): 4034-4053.

Kocsis M, Borhidi A. 2003. Petiole anatomy of some Rubiaceae genera. Acta Botanica Hungaria 45: 345-353.

Konyar ST, Ozturk N, Dane F. 2014. Occurrence, type and distribution of calcium oxalate crystals in leaves and stems of some species of poisonous plant. Botanical Studies 55:32: 19.

Koster J, Baas P. 1981. Comparative leaf anatomy of the Asiatic Myristicaceae. Blumea 27: 115173.

Kumar KNS. 2013. Macro-microscopic examination of leaves of Cinnamomum malabatrum (Burn. f.) Blume sold as Tamalapatra. Ayurveda 34: 193-199.

Kuster VC, Silva LC, Passoti L, Schneider SZ. 2018. Leaf morphology and anatomy of Jacquinia armillaris Jacq. (Primulaceae) from Coastal Restinga Environments. Iheringia 73(3): 240249.

Lailati M. 2017. Karakteristik morfologi dan anatomi daun genus Garcinia dataran tinggi. Prosiding Seminar Nasional Masyarakat Biodiversitas Indonesia 3(3): 407-411. DOI: 10.13057/psnmbi/m030319.

Li J. 2001. Systematic relationship within the Litsea complex. Thesis. Department of Enviromental Biology, University of Adelaide.

Lin CY, Tan D. 2015. The taxonomic significance of leaf epidermal micromorphological characters in distinguishing 43 species of 
Allium L. (Amaryllidaceae) from Central Asia. Pakistan Journal of Botany 47(5): 19791988.

Luna BN, Carrijo TT, Freitas MF, Barros CF. 2013. Comparative leaf anatomy of neotropical Stylogyne species (Myrsinoideae Primulaceae). Rodriguesia 64(4): 717-726.

Luna BN, Freitas MF, Baas P, De Toni KLG, Barros CF. 2017. Leaf anatomy of five neotropical genera of Primulaceae. International Journal of Plant Sciences 178(5): 362-377. DOI: 10.1086/691213.

Maiti R, Rodriguez HG, Balboa PCR, Moncivias JGM, Tijerina HAD, Diaz JCG, Kumari A. 2016. Leaf surface anatomy in some woody plants from NorthEastern Mexico. Pakistan Journal of Botany 48(5): 1825-1831.

Mantovani A, Pereira TE, Coelho AN. 2009. Leaf midrib outline as a diagnostic character for taxonomy in Anthurium section Urospadix subsection Flavescentiviridia (Araceae). Hoehnea 36 (2): 269-277.

Metcalfe CR, Chalk L. 1950. Anatomy of the Dicotyledons. Vol. I. Clarendon Press, Oxford, 243-245.

Metcalfe CR. 1987. Anatomy of the Dicotyledons Vol. III. Clarendon Press, Oxford.

Moraes PLR. 2006. Taxonomy of Cryptocarya species of Brazil. Department of Botany, State University of Campinas.

Nagani K, Kaneria M, Chanda S. 2012. Pharmacognostic studies on the leaves of Manilkara zapota L. (Sapotaceae). Pharmacognosy Journal 4(27): 38-41. DOI: 10.5530/pj.2012.27.6

Nidyasari S, Akmal H, Ariyanti NS. 2018. Ciriisasi morfologi dan anatomi tanaman manggis dan kerabatnya (Garcinia spp.) di Taman Buah Mekarsari. Jurnal Sumberdaya Hayati 4(1): 12-20.

Nishida S, De Kok R, Yang Y. 2016. Cuticular features of Cryptocarya (Lauraceae) from Peninsular Malaysia, Thailand and Indo - China and its taxonomic implications. Phytotaxa 244(1): 026-044.

Noraini T, Ruzi AR, Ismail BS, Hani BU, Salwa S, Azeyanty JA. 2016. Petiole vascular bundles and its taxonomic value in the tribe Dipterocarpeae (Dipterocarpaceae). Sains Malaysiana 45(2): 247-253.
Norfaizal GM, Noraini T, Latief A, Masrom H, Salmaniza S, Nurshahidah R. 2018. Variation in the stomatal types and anticlinal wall patterns in Malaysian Sapindaceae species. Asian Journal of Microbiology, Biotechnology and Environmental Sciences 20(2): 387-403.

Nughes LM, Colares $M$, Hernández, Arambarri A. 2013. Morfo-anatomía de las hojas de Celtis ehrenbergiana (Celtidaceae) desarrolladas bajo condiciones naturales de sol y sombra. Bonplandia 22: 159-170.

Pathirana PSK, Herat TR. 2004. Comparative vegetative anatomical study of the genus Garcinia L. (Clusiaceae/Guttiferae) in Sri Lanka. Ceylon Journal of Science (Biological Sciences) 32: 39-66.

Payne WW. 1970. Helicocytic and allelocytic stomata: unrecognized patterns in the Dicotyledonae. American Journal of Botany 57(2): 140-147.

Perrone R, Rosa PD, Castro OD, Colombo P. 2013. Leaf and stem anatomy in eight Hypericum species (Clusiaceae). Acta Botanica Croatica 72(2): 269-286. DOI: 10.2478/botcro-20130008

Priya C, Hari N. 2018. A study on leaf and petiole anatomy of endemic and vulnerable species of Garcinia. JETIR 5(12): 509-512.

Rahayu SE, Kartawinata K, Chikmawati T, Hartana A. 2011. Leaf anatomy of Pandanus species (Pandanaceae) from Java. Reindwartia 13(3): 305-313.

Ravindran PN, Babu KN, Shylaja M. 2005. Cinnamon and Cassia, The genus Cinnamomum. CRC Press, New York.

Royal Botanic Gardens. 2017. Distribution Species. http://www.kew.org. (diakses 15 Maret 2020)

Sass JE. 1951. Botanical microtechnique $2^{\text {nd }}$ edition. The IOWA State College Press. Iowa, USA.

Sattarian A. 2006. Contribution to the biosystematics of Celtis L. (Celitidaceae) with special emphasis on the African Species. PhD Thesis. Wageningen University, Netherlands.

Schadel WE, Dickinson WC. 1979. Leaf anatomy and venation patterns of the Styracaceae. Journal of the Arnold Arboretum 60(1): 837. 
Serebrynaya FK, Nasuhova NM, Konovalov DA. 2017. Morphological and anatomical study of the leaves of Laurus nobilis L. (Lauraceae), growing in the introduction of the Northern Caucasus Region (Russia). Pharacognosy Journal 9(4): 519-522. DOI: 10.5530/pj. 2017.4.83.

Seshavatharam V, Srivalli M. 1989. Systematic Leaf Anatomy of Some Indian Mangroves. Proc. Indian Acad. Sci (Plant Sci) 99(6): 557-565.

Sharma GK, Davis DA. 2001. Adaptations in leaflet morphology and epidermal dynamics in Parthenocissus quinquefolia $\mathrm{L}$. in response to environmental pollution. Journal of the Tennessee Academy of Science 76: 123-126.

Stace CA. 1965. The use of epidermal characters in phylogenetic considerations. Departement of Botany, University of Manchester. Manchester.

Stuessy TF. 1990. Plant taxonomy: the systematic evaluation of comparative data. Columbia University Press. New York.

Teixeira TR, Padua MS, Castro AHF. 2016. Leaf anatomy of Cordiera sessilis (Vell.) Kuntze (Rubiaceae). Acta Scientiarum Maringa 38(3): 355-364.

Thakur HA, Patil DA. 2011. Petiolar anatomy of some unstudied Euphorbiaceae. Journal of Phytology 2(12): 54-59.

Tholen RMDHVT, Baas P. 1978. Epidermal characters of the Celastraceae sensu Lato. Acta Botanica Neerlandica 27(5/6): 355-388

Tilney PM, Kok PDF, van Wyk AE. 1990. The taxonomic significance of anatomical characters of the leaf in the Southern African species of Canthium s.l (Rubiaceae). South African Journal of Botany 56(3): 363-382.

Turner H. 1994. Cladistic and biogeographic analyses of Arytera Blume and Myscharytera gen. nov. (Sapindaceae) with notes on methodology and a full taxonomic revision. Thesis. Hortus Botanicus.

van Cotthem WRJ. 1970. A classification of stomatal types. Botanical Journal of the Linnean Society 63(3): 235-246.

Wang Z, Sun F, Xie S, Wang J, Li Y, Dong J, Sun M, Sun B. 2017. A new species of Garcinia (Clusiaceae) from the Middle Miocene of Fujian, China, and a phytogeographic analysis. Geological Journal 54(3): 13171333.

Yang Y, Zhang L, Liu B, van der Werff H. 2012. Leaf cuticular anatomy and taxonomy of Syndiclis (Lauraceae) and its allies. Systematic Botany 37(4): 861-878. 